Original Research Paper

\title{
Analysis of Validation Development Learning Model Attainment Concept to Improve Critical Thinking Skills and Student Learning Outcomes
}

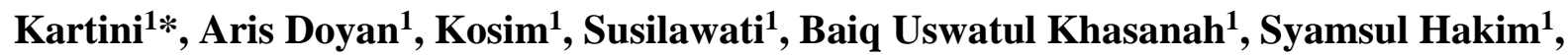 \\ Lalu Muliyadi ${ }^{1}$
}

${ }^{1}$ Master of Science Education Program, University of Mataram, Lombok, West Nusa Tenggara, Indonesia

\author{
Article history \\ Received: April 13 $3^{\text {st }}, 2019$ \\ Revised: May 15 $5^{\text {st }}, 2019$ \\ Accepted: June $20^{\text {st }}, 2019$ \\ *Corresponding Author: \\ Kartini, Master of Science \\ Education Program, University \\ of Mataram, Lombok, West \\ Nusa Tenggara, Indonesia; \\ Email: \\ gonepiece17@gmail.com
}

\begin{abstract}
This study aims to produce a product in the form of a science learning model for the acquisition of motion material concepts in valid objects, with the development path using a 4D model consisting of 4 stages of development namely define, design, develop, and disseminate. Learning tools developed are syllabus, Lesson Plain, SAS and tests of critical thinking skills and student learning outcomes. However, at this writing focused on the process of validation testing through validation tests on the development of devices made. The final result of this study is to produce valid learning development products.
\end{abstract}

Keywords: Learning Devices, Validation

\section{Introduction}

Education aims to prepare Indonesian people to have the ability to live as individuals and citizens who are faithful, productive, creative, innovative and affective and able to contribute to the life of the nation and world civilization (Depdikbud, 2013). One way is to improve the quality of education. Teachers have an important role to play in improving the quality of education. As a good educator, teachers are expected to be able to have deep knowledge and understanding of the material taught. The teacher will appear able to develop the curriculum if the teacher is able to make a syllabus that is in accordance with the curriculum, able to make a plan for implementing appropriate learning so that students reach the learning objectives.

Given the role of learning devices in determining the achievement of learning objectives, certainly a good and valid learning tool is needed. Learning devices are said to be valid if they meet the criteria for content validity and construct validity (Rochmad, 2012). Content validity shows that learning devices developed are based on the curriculum. Construct validity shows consistency between the components of the learning device. According to Santofani (2016) states that to find out the content validity can be done by matching the test material with the syllabus. Furthermore, the instrument is said to have construct validity if the items constructing the test measure every aspect of thinking. Construct validity can be known by pairing each item with each aspect in the learning objectives. an addition to assessing learning devices, the expert team also provides suggestions for improvements. According to Wibowo (2015), suggestions from these experts are used to improve learning devices.

Before the learning device is used, the learning device should have fulfilled the valid status. While Suhartini et al, (2016) stated that devices with very valid categories can be used in research with revisions according to expert advice. Likewise, the learning tools developed in this study are syllabus, lesson plan (LP), Student Activity Sheet (SAS), description questions (to measure critical thinking skills) and multiple choice questions (to measure learning outcomes) will go through the process validation by more competent experts.

From this introduction, the researcher wants to develop learning tools for concept acquisition models. The main objective of the concept acquisition model is to help students develop and build their understanding of concepts, they develop and construct concepts by examining examples of examples that they have not met before and comparing with other examples. The next goal is to develop students' critical thinking skills. The learning steps are: 1) Presenting examples, 2) Analyzing Hypotheses, 3) Cycle Analysis, 4) Closing, 5) Application (Eggen \& Kauchak, 2016). 
Critical thinking is reasonable and reflective thinking that focuses on deciding what is believed or done (Fisher, 2009). Critical thinking skills are the ability to think on a complex level and use the process of analysis and evaluation. The results of the research of Nazar et al, (2014) state that students' critical thinking skills experience an increase with the conceptual acquisition model of metabolic material.

Based on the description above, researchers are interested in developing a science learning tool model of Attainment concepts and are expected to be able to improve critical thinking skills and student learning outcomes.

\section{Method}

Research and development is carried out using the 4D development model. The development stage includes the 4D model has 4 stages, namely: define, design, develop and desseminate. The initial products developed were syllabus, LP, SAS, instruments for evaluating critical thinking skills and student learning outcomes. Data validity was obtained from the validation of three competent experts. The validation results are analyzed to determine the level of validity and suggestions from experts are used to revise the device.

Data analysis techniques for feasibility are: 1) All scores obtained from the validators for each omponent, sub-components of the assessment items are available in the assessment instrument; 2) Calculate the percentage of scores by using the equation 1 ; 3) Determine the level of validity. Determine the level of validity based on the range of values.

$$
\begin{aligned}
& P=\frac{n}{N} \times 100 \% \\
& \text { Where, } \\
& \mathrm{P}=\text { average percentage } \\
& \mathrm{n}=\text { score obtained } \\
& \mathrm{N}=\text { maximum score }
\end{aligned}
$$

Table 1: Criteria for Evaluation of Instrument Evaluation Results

\begin{tabular}{ll}
\hline Range of average values (\%) & Level of validation \\
\hline$<21$ & Very low valid \\
$21-<40$ & Not valid \\
$41-<60$ & Quite valid \\
$61-<80$ & Valid \\
$81-\leq 100$ & Very valid \\
\hline & Arikunto (2010)
\end{tabular}

In this study a minimum value is sufficient, if the validator provides sufficient value then the product or device is suitable for use in learning.

\section{Result and Discussion}

The define consists of two steps, namely conducting a problem analysis and curriculum analysis. The problem analysis conducted by researchers is to find out the characteristics of students. The results of the characteristics analysis of students found that class VIII students were generally 13-14 years old. In the 2013 curriculum analysis found basic competencies associated with motion. Analyzing straight motion, the influence of force on motion based on Newton's Law, and its application to the motion of objects and the motion of living things. Next is the determination of indicators of achievement of competencies and learning objectives that are in accordance with basic competencies demands.

At the design, the activities carried out by the researcher were to design learning devices, design learning device validation sheets and design response questionnaires students to the implementation of the SAS. In designing learning activities researchers design components contained in the syllabus, lesson plan and SAS. On designing the validation sheet and questionnaire response of the student researchers developed the aspects assessed. Every aspect has several indicators and assessment points.

The syllabus components that will be developed based on Minister of Education and Culture number of 22 of 2016 consisting of (1) subject identity; (2) school identity; (3) core competencies; (4) basic competencies; (5) basic material or learning; (6) learning activities; (7) competency achievement indicators;

assessment; (9) time allocation; and (10) learning resources.

Lesson plan components developed based on integration Lesson plan components developed based on integration number of 103 in 2013 and number of 22 in 2016 in the Ministry of Education and Culture which consists of: (1) school identity, (2) subject identity, (3) class / semester, (4) subject matter (5) learning material, (6) time allocation, (7) Core Competence, (8) Basic competencies and competency achievement indicators, (9) learning objectives (10) material descriptions learning, (11) learning approaches/models/methods, media/tools and materials learning, (13) learning resources; (14) learning steps, (15) assessment learning process and results.

The front page of the SAS consists the title of learning material, student identity, time, supporting pictures, learning objectives and instructions. Content section SAS was developed in accordance with material requirements and the attainment concept model. 
The syllabus validation sheet was made to assess several aspects, namely: (1) content, (2) language, (3) time. The lesson plan validation sheet is designed based on several aspects, namely: (1) Formulation of learning objectives, (2) content presented, (3) language. The SAS validation sheet is designed based on several aspects, namely: (1) SAS structure, (2) content components, (3) language.

The stage of the learning device produced must go through a series of assessments to produce a device that is ready to be developed. The initial product in the form of a learning device developed in this study has a characteristic that is the steps of its activities following the stages of conceptualization activities. The learning tool was assessed by three experts. Data from the expert's assessment results are then analyzed to determine the level of validity. Device validation results learning is shown in Table 2.
Table 2. The results of the learning device validation

\begin{tabular}{llll}
\hline No & Aspect & $\begin{array}{l}\text { Percentage } \\
\text { Average }\end{array}$ & $\begin{array}{l}\text { Level } \\
\text { Validity }\end{array}$ \\
\hline 1 & Syllabus & $85 \%$ & very valid \\
2 & Lesson Plan & $88,75 \%$ & very valid \\
3 & Student Activity & $86,75 \%$ & \\
& Sheet valid \\
4 & Instrument for & $86 \%$ & very valid \\
& Critical Thinking & & \\
& Skills & & \\
5 & Instrument & $86 \%$ & very valid \\
& Learning & & \\
& Outcomes of & & very valid \\
& Students & & \\
Average $86,5 \%$ & & \\
\hline
\end{tabular}

Learning devices that are developed are categorized as very valid. According to Rochmad (2012) learning devices are said to be valid if they meet the criteria for content validity and construct validity. Suhartini et al (2016) states that a very valid category device can be used in research with revisions according to expert advice. Suggestions and revised results from validator in Table 3.

Table 3. Suggestions and Revised results from the validator

\begin{tabular}{ll}
\hline No & Suggestion \\
\hline 1 & Syllabus \\
1.1. The syllabus must be formulated according to the \\
variables in the study \\
1.2. The time allocation is adjusted to the depth of the \\
material \\
1.3. Adjust writing, tabulation and location properly \\
and correctly
\end{tabular}

\section{Lesson Plan}

2.1. Adjust between learning objectives with indicators of critical thinking skills and student learning outcomes

2.2. The syntax in learning must be adjusted to time

2.3. Summarize the syntax so that the time is right Write down the learning goals following the rules of $\mathrm{ABCD}$

2.4. Writing down the lesson plan material presented at the SAS must be different

2.5. Formulating learning objectives must be in accordance with KKO

\section{$3 \quad$ Student Activity Sheet (SAS)}

3.1. Give examples to students of ways to make hypotheses

3.2. Mengusahakan gambar yang ditampilkan tidak terlalu banyak dan gambarnya lebih sketsa

3.2. Adjust writing fonts with SAS that are often used in schools

3.4. Make numbering in the formula equation

3.5. Pay attention to learning goals and adjust them to lesson plan

\section{Repair}

Improve the shape of the instrument, description (critical thinking skills), multiple choice (student learning outcomes)

Write down goals or clarify learning objectives

Arrange writing according to the rules of writing good and correct scientific work

Clarify instruments in lesson plans so that there are differences between the results of student learning outcomes and critical thinking skills

Summarize the syntax so that the time is right

Writing down learning objectives uses the $\mathrm{ABCD}$ rules

Replacing lesson plan 01 for SAS 01, and so on

Write learning objectives with more operational language

Give a hypothetical example

Change the picture on the SAS with a simpler one so that students are not confused and give information on each picture

Organize the writing and adapt it to the SAS in the school so that students do not confuse seeing different writing

Make numbering in each equation

Clarify objectives at the SAS in accordance with the lesson plan 


\begin{tabular}{|c|c|c|}
\hline No & Suggestion & Repair \\
\hline & 3.6. Use Indonesian on certain terms & $\begin{array}{l}\text { Improve English sentences with good and correct } \\
\text { Indonesian }\end{array}$ \\
\hline \multirow[t]{3}{*}{4} & $\begin{array}{l}\text { Instrument of Critical Thinking } \\
\text { 4.1. Change names in making questions with } \\
\text { pronouns and use simpler sentences. }\end{array}$ & Change names to pronouns \\
\hline & $\begin{array}{l}\text { 4.2. In making questions, it must be avoided about } \\
\text { chain issues }\end{array}$ & $\begin{array}{l}\text { Making questions that are not chain so as not to turn } \\
\text { off the thinking of students }\end{array}$ \\
\hline & $\begin{array}{l}\text { 4.3. Making instructions in working on the problem } \\
\text { must be separated from the status } \\
\text { 4.4. Making a description question must be adjusted } \\
\text { to the font that is often obtained by students at } \\
\text { school }\end{array}$ & $\begin{array}{l}\text { Separating school status with instructions, so students } \\
\text { get clarity in answering questions } \\
\text { Matching questions with question fonts that are often } \\
\text { used in school }\end{array}$ \\
\hline \multirow[t]{4}{*}{5} & Learning Outcomes Instrument & \\
\hline & 5.1. Simplify the sentence used & $\begin{array}{l}\text { Using effective sentences so that students quickly } \\
\text { understand the meaning of the problem. }\end{array}$ \\
\hline & $\begin{array}{l}\text { 5.2. Making multiple choice questions is adjusted to } \\
\text { the rules of the right answer }\end{array}$ & Change each choice in lowercase \\
\hline & 5.3. Using one space and table not colored & Change font letters in tables and not colored \\
\hline
\end{tabular}

Good test questions should go through two steps, namely test validation and reliable tests. The analysis is carried out through validation, reliability, level of difficulty, and differentiation of problems as determined, where students are directed to indicators of critical thinking and indicators of achievement of competence.

\section{Conclusion}

Based on the results and discussion above it can be concluded that the science learning device in the form of syllabus, Lesson Plan (LP), Student Activity Sheet (SAS), Instrument of Critical Thinking and Learning Outcomes Instrument for the model of the concept developed has fulfilled the valid content and valid construct. The suggestions and revisions given by the validator are presented as input to get a more valid device.

\section{References}

Arikunto, S. 2010. Research Management. Jakarta : Rineka Cipta.

Depdikbud. 2013. Permendikbud No. 81a. About the Implementation of the Curriculum General Guidelines for Learning. Jakarta: Depdikbud.

Eggen, D. P., dan Kauchak, P. D. 2016. Learning Strategies and Models. Jakarta: PT Indeks.

Fisher. 2009. Critical Thinking: An Introduction. Jakarta: Erlangga.

Nazar, M. 2014. Application of the Concept Attainment Model to student learning outcomes in metabolic material. Jurnal Biologi Edukasi. 2 (1).
Rochmad. 2012. Design of Mathematics Learning Tool Development Model. Jurnal Kreano. 3 (1).

Santofani., A., Rosana, D. 2016. Pengembangan Tes Kreativitas pada Pembelajaran Fisika dengan Pendekatan Inkuiri pada Materi Teori Kinetik Gas. Jurnal Inovasi Pendidikan IPA. 2 (2).

Suhartini. E., Supardi, I., Agustini, R. 2016. Pengembangan Perangkat Model Inkuiri Terbimbing Berbantuan Teknik Mind Mapping untuk Meningkatkan Penguasaan Konsep dan Kemempuan Berpikir Kreatif Siswa SMP. Jurnal Pendidikan Sains Pascasarjana Universitas Negeri Surabaya. 5 (2).

Wibowo. A., dan Laksono, E. W. 2015. Pengembangan dan Implementasi Perangkat Pembelajaran IPA Berbasis Inkuiri. Jurnal Inovasi Pendidikan IPA. 1 (2). 